\title{
1 \\ China and the responsibility of power
}

\author{
Yongjin Zhang and Greg Austin
}

Why does China behave as it does in its foreign policy? How and why does China behave differently from other Great Powers in international society? How does China's understanding of the responsibility associated with its rising power explain its international behaviour? In what sense can we argue that China has become more (or less) responsible in international relations? In China's search for its Great Power status, how do domestic politics and historical experience matter in its understanding of the responsibility of power? Does China think it is well served by a responsible approach to the rights and duties bestowed on it by international society? How do others evaluate whether China is living up to its obligations as a rising power? These are among a particular set of questions that individual essays published in this collection reflect on and debate. Collectively, this book explores a gap in the existing literature on the studies of Chinese foreign policy and focuses on whether and how a particular idea-the idea of the responsibility of power-helps to shape as well as explain China's changing behaviour in international relations.

The rising power of China has been one important theme in the discourse of post Cold War international relations. Recent and current debates have revolved around two important questions. What are the implications of the rise of China for regional and global international order? And how should others, particularly 
the United States, respond to the rise of China?' On the first question, a realist reading suggests that changing power relations, particularly those of a rising power vis-à-vis the pre-eminent power (that is, China vis-à-vis the United States), will inevitably lead to conflicts and even war. Further, China is revisionist and destabilising because of its historical grievances and irredentist agenda. It is bent on challenging and changing the existing international order. A realist reading is quick to point out that, historically, the rise of Japan and Germany as two have-not powers has provoked major wars. Even a liberal reading of the rise of China is likely to reinforce the realist wisdom. China is the remaining Leninist state. The Chinese Communist Party still presides over an authoritarian political system and repressive regime that is antithetical to democratic values. Naturally, Beijing continues to hold conflicting worldviews about the nature and structure of the international system. The distorted relationship and tensions between state and society and the lack of social balance of power in China's statesociety complex also makes a strong China more of a threat than a contribution to peace and stability. ${ }^{2}$ Such readings underlie the variegated interpretations of the 'China threat'.

On the second question-how best to respond to or manage the rise of China-proposed strategies in the debates differ sharply, ranging from containment to constrainment, to conditional, constructive and comprehensive engagement. ${ }^{3}$ Realist arguments emphasise the containment and constrainment of China, whereas liberal arguments favour engagement. Either implicitly or explicitly, realist arguments in general posit that China is a classic dissatisfied but rising power like Nazi Germany and the former Soviet Union. China and the United States are therefore destined to clash with each other or become strategic rivals, or at least strategic competitors. ${ }^{4}$ For realists, the historical lessons of the failure of the British appeasement policy in the 1930s and the success of US containment policy during the Cold War support their arguments for the containment strategy. ${ }^{5}$ Some further argue that, as China's approach to international relations remains realpolitik, only concerted power can deter or constrain it. In East Asia, therefore, a new balance of power should be established for that purpose. ${ }^{6}$ 


\section{Introduction}

Realists believe that liberal arguments for engaging China are based on shaky ground. It is true that economic interdependence between China and the world economy is intensifying. Economic interdependence alone, however, is insufficient to change Chinese behaviour decisively and is at the mercy of Chinese leadership's cold calculation of cost and benefit. It is also true that China's participation in regional and global international institutions is growing. Regional international institutions in East Asia, in contrast to Europe, are, however, too weak to exert any real influence in modifying China's security policy and behaviour in the region. While engagement policy may encourage the Chinese government to liberalise internally, other domestic variables such as succession politics and the vulnerability of the political system are more decisive of the future of China's democratisation.

The contributors to this volume share many common concerns with the current debates. We also believe that the rise of China is central to the future shape of the regional and global international order and China's international behaviour will change as its power grows. Further, China's growing power needs to be managed carefully to minimise its disruptive effect on the international system. We differ, however, on the assessment that the rising Chinese power is necessarily and inevitably destabilising and threatening. A crucial variable here is China's attitudes towards the responsibility of its rising power in international relations. Does China view power as a means or an end, and a means to what end? What is the conception among Chinese élites of China's responsible role in international relations? As a rising power, does China share with other Great Powers similar understanding of their responsibility for managing the international system? Where is the gap? How can international society induce a rising China to play an increasingly responsible part in the emerging international order? Answers to these questions, we argue, have important bearings on our understanding of the implications of an ascendant China for the future international order.

We seek therefore to join the debate by investigating this missing dimension in the current discourse on the rise of China and to invigorate the debate by taking us beyond the sterile discussions 
of a rising power vis-à-vis a pre-eminent power. Regardless of one's theoretical preferences, the role of theory is to aid in understanding and explaining. There are two additional reasons why this line of enquiry should be pursued. First, China has often been stigmatised as an irresponsible power and a 'rogue state'.? Evidence drawn from, for example, China's evolving arms control policy and its policies towards North Korean nuclear and missile programs, as well as its behaviour during the Asian financial crisis in 1997-98 and its missile exercise in the Taiwan Strait in 1996 is, however, inconclusive and contradictory at best. Such contradictions need to be analysed carefully. Second, unique among Great Powers, China has developed a set of uneasy and unusual social relations with global international society. Our investigations must be embedded in that social context and are to contribute to our understanding of that social context.

Power exacts responsibility. Even in the anarchical and hierarchical world of international relations, this conventional wisdom remains unpalatably true. ${ }^{8}$ Hedley Bull once explicitly argued that it is precisely because of the embedded inequality of states in terms of power in international society that Great Powers enjoy special rights and privileges at the same time when they assume duties and managerial responsibilities for maintaining and sustaining international order. Great Powers also have a greater stake in the existing international order. ${ }^{9}$ Bull argues more specifically that Great Powers contribute to international order 'by managing their relations with each other; and by exploiting their preponderance in such a way as to impart a degree of central direction to the affairs of international society as a whole'. ${ }^{10}$ The persistent vitality of G7 (now G8), the uncompromising privileged status of the exclusive nuclear powers club, and recent debates over the reform of the United Nations Security Council are testimony of the continued relevance of Bull's arguments after the end of the Cold War. Two points need to be made here, though. First, the concept of the responsibility of Great Powers is fundamentally different from that of the state responsibility. Whereas state responsibility is legally and explicitly defined in international law (for example 
the responsibility to protect aliens and their property)," Great Power responsibility is politically as well as morally postulated implicitly rather than explicitly. It rests on shared understanding principally among Great Powers. Collective expectations of international society therefore underlie the conceptualisation of the responsibility of power. Second, in his discourse on the duties and stake of Great Powers in international order (largely conducted in the 1970s), Bull clearly privileges order over justice in world politics, although he is not entirely comfortable, and is sometimes ambivalent, as to where he situates justice vis-à-vis order. As lan Harris has noted, Bull's ambiguity in his treatment of justice results from lack of an enquiry into international ethics. ${ }^{12}$ Further, Bull's discussions suggest that the rights and duties of Great Powers are mostly, if not exclusively, structurally determined. There is little elaboration in Bull's discussions about how the domestic constitutions of individual states shape their attitudes towards power and their understanding of the responsibility associated with it. ${ }^{13}$ Discourse on the responsibility of power which is deprived of normative content and blind to the role of domestic institutions and ideas can no longer be either justified or left unchallenged.

The responsibility of power, arguably one of the most fundamental concepts in international relations, remains one of the most underexplored in international relations theory. We are not here, however, to launch a study of the ethics of power and responsibility in international relations. Important as it is, it belongs to an entirely different enquiry. ${ }^{14}$ Our purpose here is simply to highlight how notoriously difficult ethical considerations of power and responsibility can be and why they are likely to remain contentious and controversial. Ethical judgment of how and whether a power fulfils its responsibility is ultimately subjective. Difficulties in investigating Chinese behaviour in this kind of analytical construct are further amplified by the differences in Chinese philosophical tradition and political culture that sustain China's historical assumptions about power and responsibility. ${ }^{15}$ Whereas a system of legal and institutional checks on the exercise of political power has been developed in the Western political tradition, the Chinese 


\section{Power and Responsibility in Chinese Forelgn Policy}

political tradition has relied more on the ethical and moral character of rulers to restrain the abuse of power.

This is not in the least the only complexity to consider. Chinese revolutions in the twentieth century and China's turbulent relations with other Great Powers have also conditioned its understanding of the responsibility of power. In particular, China's unique experience of socialisation into international life in the second half of the twentieth century has helped produce a special set of social relations between China and the changing international society. As Yongiin Zhang argued recently, Revolutionary China's relationship with international society in the 1950s and the 1960s is best characterised as alienation rather than isolation. ${ }^{16}$ It is not hard to imagine why Revolutionary China did not feel obliged to take any social responsibility to an international society of which it was not regarded part and in which its legitimacy was tenaciously denied. In this context, it also makes perfect sense to talk about how and whether China is (re)joining the world. ${ }^{17}$

Yet, China's position in international society remains a curious one. China has been a declared nuclear power for almost forty years and has been one of the Permanent 5 in the United Nations Security Council for more than thirty years. It is now universally regarded as a rising power. Its membership in the Great Power club is nevertheless at best contentious. In the post Cold War international society, inference more often than direct reference is made to China being a 'rogue state'. China's full membership in international society continues to be questioned, but from a different angle. Human rights and democratisation are now the litmus test, as Rosemary Foot argues in her chapter. ${ }^{18}$ As the lingering Westphalian system becomes less tolerant of political heterogeneity, ${ }^{19}$ the nature of the domestic political system, democratic process and institutional set-up become increasingly significant in defining not only the domestic legitimacy but also the international legitimacy of a particular regime.

It is against this background that contributors to this volume conduct their conceptual and empirical investigations. It is in this context, we believe, that power and responsibility in Chinese foreign policy should be evaluated and understood. 


\section{Responsibility: an evolving concept and a moving goalpost}

The first two chapters analyse conceptually the issue of responsibility in greater depth than the others. Rosemary Foot and Gerald Chan identify different aspects of the question of responsibility in the international system. Their perspectives are mutually complementary in that Foot looks at the question from outside-in, that is, largely from the perspective of international society, whereas Chan examines the problem from inside-out and offers a Chinese perspective.Their analyses taken together suggest an interpretation as follows. The concept of the responsibility of power has not remained static in recent decades. It is for some purposes a highly subjective concept, and therefore it may remain difficult, if not theoretically impossible, for China to ever actually meet a benchmark of responsibility.

Foot notes the principle, which in our view is fundamental, that the privilege of statehood being recognised as a state by the international community of states-carries with it an obligation to contribute to world order. She then sketches how the concept of responsibility in meeting that obligation evolves through three phases, from a more basic concept relating to the discourse and practice of diplomacy and embrace of international law, through a more expansive phase of not just minding one's own business, but also contributing to a series of multilateral regimes that 'make up the substance of international life' in a world marked by far more interchange and more mutual responsibility. The third phase is one marked by a new 'willingness to promote the protection of individual security, or human rights, and to foster legitimate forms of representation' of popular will.

Foot notes that determination of a particular state's level of responsibility will be in itself a political act, but suggests that some objectivity (or at least consensus) is possible in respect of China by reference to the degree to which it meets the measures of responsibility in the first two phases mentioned above. Foot suggests, as do several authors in this volume, that by these standards China has been quite responsible. She also notes 
appropriately a lack of scholarly consensus on the motivations for this pattern of behaviour by China. Is China a 'system maintainer' or a 'system exploiter'?

It will be much harder, Foot concludes, for China under the current system of government to meet the standards of responsibility in the third phase of evolution of international society-respect for human rights and appropriate representation of popular will. Until China meets this standard, Foot believes that 'China will remain outside global society'.

Chan takes the discussion into another dimension, proceeding from the view that, in Chinese tradition, the level of responsibility that a person is obliged to take depends on their position in a hierarchy of power. He links this to the rise in China's power, and asserts-correctly in our view-that Chinese leaders and many ordinary Chinese people expect China to be accorded a level of responsibility relative to its rising power. This is clearly different, Chan notes, from being seen or judged as responsible by other members of international society. There seems to be no evidence, in his view, that Chinese leaders have any conscious thought that China should be seen to be responsible to the world when they make foreign policy decisions. Chan also makes an interesting distinction that he thinks does exist in the minds of the Chinese leaders that the type of responsibility a state possesses is linked to whether it disposes of soft power (cultural appeal) as well as hard power.

Chan concludes that it is indisputable that China is more responsible now than it was two decades ago. Second, he concludes that if we want to analyse how responsible China is, then this must be a comparative exercise: how does China's level of responsibility compare with other powers?

\section{Domestic changes and the Party-state: international implications}

The next two chapters address the internal foundations of the power of the Party-state. In Chapter 4, GregAustin focuses broadly on leadership perceptions of the government's power against the 
backdrop of a rapidly changing society, whereas You Ji addresses in Chapter 5 the gradual but inevitable divorce of the armed forces from the Party. Both chapters identify important implications of these significant domestic changes for China's international power and responsibility, though these are deliberately asserted rather than elaborately argued. These assertions are quite justified in both cases, however, since any in-depth analysis of the very complex relationships emerging in domestic political power does not leave room for much analysis of the international implications.

Austin sketches the political and social effects of the whirlwind of economic reform in what he sees as a weak state. The Chinese Communist Party (CCP), he argues, is facing mounting discontent on too many fronts and, on the basis of recent evidence, seems to be losing in Western Xinjiang. Austin sees the Chinese state as weak not only because of these mounting challenges, but also because the political system itself is fragile. The Communist Party has withered on the vine and no new substitutes for it have been found, though neo-authoritarianism has surfaced, in rhetoric at least, as a possible alternative. The strike-hard campaigns might lead some to conclude that this choice has been made, but Austin contends that the strike-hard campaigns are a reflection of the weakness of the state and the nervousness of its leaders, and not evidence of a post-Communist transition to a stable form of authoritarianism.

Austin concludes that the "very foundations of domestic governance, and therefore of China's international position, remain fragile'. In his view, the battle for the future of Chinese politics will be fought between more radical, more liberal minded reformers and less radical, less liberal reformers in the Communist Party and by the supporters of both camps in the armed forces and security services (such as the Ministries of State Security and Public Security). He also concludes that the scale of disadvantage and disaffection in China is so great and growing so quickly that major social and political turmoil seems inevitable. It will be in the response to such outbreaks of disorder that the future of the Party-state and its policies will lie. If the more liberal reformist elements of the Party come to dominate these decisions, coercion 


\section{Power and Responsibility in Chinese Forelgn Policy}

will be avoided in favour of spreading democracy (and the blame) and by patching up regional welfare problems on an ad hoc basis. If the less liberal, though still reformist, elements in the leadership dominate decisions, then sustained resort to coercion and a deterioration of the social contract are inevitable. If the discontent is not defused more quickly and more effectively than it has been so far, the outcome will almost inevitably be more consistent resort to force and fragmentation of the society.

You Ji reviews the slowly changing 'marriage' between the People's Liberation Army (PLA) and the CCP-a direct consequence of the fundamental nature of the authoritarian state, where the armed forces must serve an internal security role. He predicts an eventual divorce or, more interestingly, 'widow' status for the PLA, since the CCP may well simply die. Under either scenario, he sees a much more 'normal' constitutional relationship between the PLA and the Chinese government. That is, however, his longer-term prediction. Whatever happens, he notes, each side in the relationship has become weaker, and the military in particular now has to vie for influence alongside a larger number of other interest groups with increased influence.

You Ji's assessment of the shorter term is based on his view, with which it is difficult argue, that for the last two decades the two sides have been getting on quite well. He complements the civilian government for its performance in striking a good balance between allowing the military to feel that it occupies an important place in the political order while at the same time advancing a broader development agenda and denying the PLA undue influence in domestic politics. At the same time, he concludes that the PLA is 'still the most awesome political institution' in the country because of its size and physical power, because of its popular support, and because of its 'constitutional status' established through the highly autonomous Central Military Commission of the CCP. The main trend though has been towards professionalisation and depoliticisation of the armed forces, and this trend has been strong.

You $\mathrm{Ji}$ sees the PLA and the CCP leaders as being in general agreement over the strategic threats to the country, but says there 


\section{Introduction}

has been visible discord about relative priorities in two important policy areas-military posture (more or less defence expenditure) and Taiwan (more or less military pressure). He sees a continuation of the dominance of the line of the civilian leadership on both counts - except perhaps in the event that a crisis is forced on China, in which case the civilian leadership may be forced to side with a more aggressive military posture demanded by the PLA in order to avoid being tarred with the brush of betraying national interests.

\section{Towards a responsible power? Practice and evidence}

Chapters 6-9 provide brief case studies and offer accounts of how China's recent international behaviour in specific issue areas reflects on the question of whether and how China can be said to have become more responsible in international relations. In Chapter 6, Ann Kent discusses what China's participation in international organisations tells us about its learning about the responsibility of power. Stuart Harris, in Chapter 7, examines China's recent diplomacy in Northeast Asia. While in Chapter 8, He Baogang, addresses Beijing's policy toward Taiwan's bid for a UN seat, Gary Klintworth takes up in Chapter 9 controversial issues surrounding China and arms control.

\section{China and international organisations}

Ann Kent introduces her article with some general propositions that seem in close agreement with those of other authors. The most important of these is that 'participation in international organisations both confirms sovereignty and constrains it'. She notes that the power conferred on states by such participation is 'balanced by the increased responsibility such participation entails'. On the strength of these propositions, Kent gives an overview of how China's participation in international organisations 'sheds light on its practical understanding of power and responsibility'.

Some authors in the volume take the view that China is not too different in its interest-based approach to responsibility from other 
powers, but Kent pays more explicit attention to this proposition and gives a good succinct statement of it. What does single China out, according to Kent, is that it has had a 'steep learning curve, mediated by its own ambitions, changing perceptions and unique perspectives'. In sketching these perceptively, Kent reminds us of China's 'self-constructed identity as a Club of One'; of China's special place as the one among the five Permanent Members of the Security Council which has to be courted more than the others, of China's tendency to free-ride on some big issues (thus evading responsibility), and of the pragmatic nature of Chinese foreign policy in spite of its articulation in highly principled and absolute terms. One of the most important observations in this section of Kent's chapter is that 'China's attitude to the international rule of law and its behaviour within international organisations is heavily influenced by its attitude to the domestic rule of law and its political culture'.

Kent concludes that China has both learned responsibility from its role in international organisations as well as learned the benefits of the appearance of being responsible. She notes that 'China's power has been enhanced by its willingness to negotiate its sovereignty'. At some domestic political cost, China continues to support international society and global norms because "just as the world needs China, China needs the world'.

\section{Northeast Asia}

Harris' analysis of China's diplomacy in Northeast Asia begins with some theoretical observations about the international system and norms that put him in close agreement with the general conclusions of Foot and Chan-there are some fairly basic standards which allow for some assessment of responsible behaviour, but these norms (such as peaceful resolution of disputes, respect for sovereignty, and appropriate engagement with international community regimes) can change in their subjective content over time. Harris therefore looks to China's Northeast Asia diplomacy for evidence of 'cooperative relationships in conformity with generally accepted international norms'. 


\section{Introduction}

Harris, echoing Chan's arguments, recognises that China's approach to international relations may not always be articulated in ways that conform to the concept of responsibility as it is understood in the West. He argues, however, that it is possible to track its behaviour against this benchmark, although it is difficult, he concedes, to ascribe motivations in all cases of China's foreign policy behaviour. Harris notes that realist-style interests of China are often visible and even prominent in China's foreign policymaking but also sees alongside these explicit foundations of China's behaviour a number of implicit ones, which he elaborates in his examination of China's recent diplomatic practice in Northeast Asia.

In a country-by-country review of China's diplomacy in Northeast Asia from an interests-based perspective, which is far too comprehensive to summarise easily here, Harris produces some important observations that reflect the views of some other authors within this volume to an extent. In discussing Chinese policy toward Xinjiang as an issue in Sino-Russian relations, Harris notes, as Foot did in general terms, that China's use of draconian internal repression measures in pursuit of what is definitely a legitimate security interest 'conflicts with what would be widely seen as the appropriate norms'. He notes that China, through the declarations of the Shanghai Five, is trying to reassert its view of the unacceptability of external interference in what it would still like to see as internal affairs.

In reviewing Sino-Japanese relations, Harris notes what appears to be a deeply ingrained Chinese instinct to avoid war with Japan, an instinct arising from the experience of war. On the US relationship, he notes the survival of some ideologicallymbased perspectives from an earlier era that give a competitive flavour to China's diplomacy. Harris notes that China sees and accepts considerable responsibilities toward regional stability in restraining North Korean missile developments. Harris' general concluding assessment is even more telling: the threats to Northeast Asian stability and peace are not likely to arise from any abrogation by China of its responsibilities, but from other causes. 


\section{Taiwan}

A fresh look at the China-Taiwan relationship from the perspective of China's responsibility in the international system is offered by He Baogang. He confirms Chan's intuition that for China, the greater its power, the greater the sense of responsibility it is likely to take or want in respect of the international system. Interestingly, He suggests that this is also the expectation of the international community - the more powerful a state, the greater its responsibility. He appears to reject instinctively a realist interpretation of international affairs, but contends that the proposition about the link between power and responsibility is 'not a moral issue' but a 'real political matter' (by which we infer 'realpolitik').A state like China, he says, has so many impacts on the world, especially its neighbours, that it must bear responsibility to them.

He's chapter is more specifically about China's approach to Taiwan's bid for a seat in the United Nations. Starting from the proposition that China's past position on Taiwan was a manifestation of the traditional concept of sovereignty, He argues that China can afford to exploit the flexibility of the sovereignty norm to take an interest-based approach to the Taiwan problem. He warns that, if China does not do this, the thorny question of Taiwan's representation in the United Nations will continue to raise its head throughout this century. The suggested innovation is to work for Taiwan's admission to the United Nations in a second China seat, rather than a separate Taiwan seat. Citing the precedents, He gives an exposition of how the change in China's position could be justified within the framework of its existing rhetoric on the Taiwan issue.

He's approach provides corroboration for some of the general conclusions presented in the chapters by Foot and Chan. There is room for a third-wave approach to sovereignty as something far from absolute. He goes further, saying that China's practice on sovereignty has already gone beyond strict adherence to its rhetoric on the sacredness of sovereignty. He cites the adjustments seen in China's Taiwan policy as evidence of its 'learning' about the possibilities of a flexible approach to the concept of sovereignty. 
Returning to the interest-based analysis we have seen in other chapters, He concludes that the only question now is whether China's political leaders are prepared to bear the political costs associated with this innovative approach, an approach which would truly demonstrate that China had reached a very high level of maturity in its appreciation of the responsibility now falling on its shoulders as a rising Great Power.

\section{China and arms control}

In his analysis of China's responsibility in acceding to, and then complying (or not complying) with, arms control regimes, Gary Klintworth is the only author in this volume to confront head-on the main source of the big questions about China's current position in the international community. There is no doubt that the question derives in large part from a 'black view of China' and that the currency and prominence given to the question is influenced largely by trends in US-China relations. Klintworth correctly observes that it is only the United States with its intelligence assets that is able to tick or cross the box on China's arms control compliance record. He does not offer a detailed analysis of the 'black view', preferring instead to cite one very good example of it. He contrasts this 'black view' with the US government's view during the second Clinton Presidency, which gave China a pretty good report card on compliance.

Klintworth's chapter, like others, is appropriately couched in terms of the theoretical debate about learning and motivations, though these aspects are not discussed at length. He canvasses two broad options for explaining China's unambiguous move to significant participation in a variety of arms control measures. The first is the basic instrumentalist one, that 'China's interest in arms control stems solely from concerns about realpolitik, defined in terms of a concern about China's global image and a desire to rein in the power' of the United States or Russia. The second flows from what Klintworth implies is a genuinely felt conviction in China, one of support for the 'same common security values as the United States'. He says that China wants to reduce global tensions where possible, especially in its relations with the United 
States, in order to concentrate on economic development. At the same time, he is prepared to admit that in the longer term, this motivation may transform itself in a way which makes its current arms control commitments seem but an 'interim ploy pending China's attainment of superpower status'.

The Klintworth chapter provides one of the best catalogues of China's arms control record that is available in brief form. His article appropriately concludes with some observations about differences between the United States and China on national missile defence that go to the heart of a sophisticated understanding of the dual nature of responsibility - on the one hand, the Great Power's obligation to comply and behave, and on the other, an obligation for it to oppose (through peaceful dialogue) what it believes is unacceptable international behaviour.

\section{Contextualising China's understanding of power and responsibility}

In a tantalising theoretical and historical essay on China's identity construction and the question of responsibility in international society, Yongjin Zhang in Chapter 10 addresses in a different fashion some of the issues flagged by Kent when she talked of China's steep learning curve mediated by its 'ambitions, changing perceptions and unique perspectives'. Zhang discusses China's 'selfconstructed identity', but poses this in the context of mutually constructed identities. He asks: 'if identity construction is mutual, that is, it is constructed by distinguishing self against the Other, then how does perceiving China as the Other constitute part of China's identity formation?' Interestingly, he asks, 'why is there such a persistent dichotomy of China vis-à-vis the world (theWest writ large)?'

The central analytical concern of Zhang's essay is to problematise China's security. Zhang begins with an important set of issues rarely addressed in commentary on China's security posture: 'How and why do the Chinese élites perceive what as the main problems for China's security?' Taking an inside-out perspective, Zhang looks at what he sees as the three most penetrating and transformational 


\section{Introduction}

social experiences of China since 1949, namely, revolution, war and reform. He offers a series of interpretations, based on a sociological approach, as to how these three domestic social processes have significantly affected China's security conceptions and behaviour. He argues that it is these domestic social processes, interacting with the same social processes in international society, that have contributed significantly to China's identity construction of self vis-à-vis the Other. Such interactions have also made China a persistently insecure power and helped produce China's insecurity complex. For these reasons, Zhang suggests, revolution, war and reform as social processes in both China and international society and their interactions constitute an important social context within which proper understanding and judgment of China's attitudes towards power and responsibility can be evaluated.

The chapter by Zhang is in the tradition of historical sociology, tracing the direct impact of the broad social upheavals on perceptions of security. But it appears to have two other intertwined approaches. The first, an explicitly stated proposition, is that revolution, war and reform are not seen as purely domestic Chinese experiences, and for this reason the real sociological significance of these events can only be understood if the link between them and international society is fully appreciated. The second, more subtextual in nature, is that the issues of revolution, war and reform were so central in the formation of the Chinese élite and so traumatic that each of these as a process has had a deep impact on the cognitive processes of Chinese élites, an impact that extends beyond the conscious or unconscious memories of specific events.

We do not pretend that the essays in this book have provided answers to all the questions that were posed at the beginning of this introduction. This is not, after all, the purpose of this book. Our contributors perhaps differ as much as they agree on the question of subjectivity and perspectives in their evaluation of power and responsibility in Chinese foreign policy. We do hope that this collection suggests more lines of thought than it elaborates and opens up new areas of enquiry that go beyond the simple caricature of China as an erratic state and an irresponsible power. 


\section{Power and Responsibility in Chinese Foreign Policy}

\section{Notes}

1 International Security has carried in the last few years a number of essays that engage in such debates. These include in particular, Avery Goldstein, 'Great expectations: interpreting China's arrival', International Security, 22, no.3 (Winter 1997-98), 36-73; David Shambaugh, 'Containment or engagement of China? Calculating Beijing's response', International Security, 21, no.2 (Fall 1996), 180209; Gerald Segal 'East Asia and the 'Constrainment' of China', International Security, 20, no.4 (Spring 1996), 107-35; and Thomas J. Christensen, 'China, the US-Japan Alliance and the security dilemma in East Asia', International Security, 23, no.4 (Spring 1999), 49-80. The above essays are now published, with a few others, in a convenient collection by Michael Brown et al. (eds), The Rise of China (Cambridge, Massachusetts: MIT Press, 2000).

2 On the social balance of power, see John M. Hobson and Leonard Seabrooke, 'Reimagining Weber: constructing international society and the social balance of power', European Journal of International Relations, 7, no.2 (2001), 239-74.

3 For a brief summary of the national debate within the United States on this issue, see Michel Oksenberg and Elizabeth Economy, 'Introduction: China joins the world', in Elizabeth Economy and Michel Oksenberg (eds), China Joins the World: progress and prospects (New York: Council on Foreign Relations Press, 1999), in particular, Pp. 7-15. Oksenberg and Economy have identified two groups which they call 'accommodationist' and 'confrontationist'. See also James Shinn (ed.), Weaving the Net: conditional engagement of China (New York: Council on Foreign Relations Press, 1996); and Ezra F. Vogel (ed.), Living with China: U.S.-China relations in the twenty-first century (New York: Norton, 1997).

4 See Richard Bernstein and Ross H. Munro, The Coming Conflict with China (New York: A.A. Knopf, 1997); and David Shambaugh, 'SinoAmerican strategic relations: from partners to competitors', Survival, 42, no.l (Spring 2000), 97-115.

5 Such a containment strategy, in Sean Lynn-Jones' words, 'usually implied treating China as a potential military adversary, attempting to limit its economic growth, restricting its accesss to militarily significant technologies, punishing China for violating human rights, and strengthening US alliances and military capabilities that are at least potentially directed against China'. See Sean M. Lynn-Jones, 'Preface' in Michael E. Brown et al (eds.), The Rise of China, xii. 


\section{Introduction}

6 See in particular Paul Dibb, Towards a New Balance of Power in East Asia: what are the risks as the Asian balance of power undergoes a fundamental change? (Oxford: Oxford University Press, 1995); and Thomas J. Christensen, 'Chinese Realpolitik', Foreign Affairs, 75, no.5 (September 1996), 37-52.

7 For a caricature of different perceptions of China, see David Lampton, 'China', Foreign Policy, no.llo (Spring 1998), 13-27.

8 For the most recent debate, see Alberto R. Coll, 'Introduction: American power and responsibility in a new century', Ethics and International Affairs, 14, (2000), 3-10; and Tony Smith, 'Morality and the use of force in a unipolar world: the 'Wilsonian moment'?', Ethics and International Affairs, 14, (2000), II-22.

9 See Hedley Bull, The Anarchical Society: a study of order in world politics (London: Macmillan, 1977), 200-29.

10 lbid, 207.

1 For state responsibility in international law, see, among others, lan Brownlie, System of the Law of Nations: state responsibility (Oxford: Clarendon Press, 1983).

12 lan Harris, 'Order and Justice in 'The Anarchical Society', International Affairs, 69, no.4 (October 1993), 725-41.

13 In dismissing Revolutionary France and Hitler's Germany as Great Powers, Bull only stated that '[s] tates which, like Napoleonic France or Nazi Germany, are military powers of the first rank, but are not regarded by their own leaders or others as having these rights and responsibilities, are not properly speaking great powers'. Bull, The Anarchical Society, 202.

14 See for example, DanielWarner,An Ethic of Responsibility in International Relations (Boulder, Colorado: Lynne Rienner, 1991); and Stanley Hoffmann, 'Political ethics of international relations', Seventh Morgenthau Memorial Lecture on Ethics and Foreign Policy (New York: Carnegie Council on Ethics and Foreign Affairs, 1988).

15 For a succinct and vigorous discussion of historical assumptions of power and responsibility in the Western political thought, see Leonard Krieger, 'Power and Responsibility: historical assumptions', in Leonard Krieger and Fritz Stern (eds), The Responsibility of Power: historical essays (London: Macmillan, 1967), 3-33.

16 See Yongin Zhang, China in International Society since 1949: alienation and beyond (Basingstoke: Macmillan, 1998).

17 Oksenberg and Economy, China Joins the World, is the most recent example. 
18 This follows a similar line of arguments by Andrew Nathan and Strobe Talbott, among others. Andrew Nathan, for example, argues that China should 'behave in a way [in terms of human rights] that does not offend the conscience of that [international] community' in return for the benefits of full membership. Andrew Nathan, 'Influencing human rights in China', in James R. Lilley and W. L. Willkie (eds.), Beyond MFN: trade with China and American interests, 80. Strobe Talbott, Deputy Secretary of State of the first Clinton Administration was more explicit, stating, 'We believe China cannot be a full partner in the world community until it respects international obligations and agreements on human rights, free and fair trading practices, and strict controls on the export of destabilising weapons and military technology'. Strobe Talbott, 'US Deputy Secretary of State Strobe Talbott's speech to the Japan National Press Club on 25 January 1995' (Washington, DC: US Department of State, 1995). For theoretical arguments on human rights as legitimising norms, see Jack Donnelly, 'Human rights: the new standard of civilisation?', International Affairs, 74, no.l January 1998), 1-23.

19 See K.J. Holsti, 'Dealing with dictators: Westphalian and American strategies', International Relations of the Asia-Pacific, I (2001), 51-65. 